\title{
West-African Modes of Mobilisations Confronting EU Mobility Regimes*
}

\section{Les modes de mobilisations Ouest-Africaines face à l'externalisation des frontières Européennes}

\author{
Julia M. Söhnholz ${ }^{1}$
}

\begin{abstract}
This article explores West-African modes of mobilisations confronting the externalisation of European borders. At the hands of a secondary data analysis, this article critically examined the most recent publications in relation to this topic, guided by the following research question: How do West-African modes of mobilisations challenge EU mobility regimes? This research identified governments, local organisations, (potential) migrants, expelled migrants, media, academia and writers and transnational social movements as relevant actors with different modes of action. This research suggests that there are multiple West-African modes of mobilisations that challenge EU mobility regimes, confront the problematisation of non-sedentary lifestyles and see mobility as a strategy and a solution for a bottom-up process of globalisation and as an inherent part of West-African mobile societies; existing next to African modes of mobilisations that have become part of EU mobility regimes. The objective of this research is to promote future research by increasing the visibility and political agency of the transformative possibilities of African modes of mobilisations.
\end{abstract}

Keywords: Mobilisation, EU mobility regimes, West-Africa.

Résumé: Cet article explore les modes de mobilisations ouest-africaines face à l'externalisation des frontières européennes. Dans le cadre d'une analyse des données secondaires, le présent article a examiné d'un œil critique les publications les plus récentes sur le sujet, guidé par la question de recherche suivante : Comment les modes de mobilisation ouest-africains remettent-ils en cause les régimes de mobilité de l'UE ? Cette recherche a identifié les gouvernements, les organisations locales, les migrants (potentiels), les migrants expulsés, les médias, les universitaires, les écrivains et les mouvements sociaux transnationaux comme des acteurs pertinents avec différents modes d'action. Cette recherche suggère qu'il existe de multiples modes de mobilisation ouestafricains qui remettent en question les régimes de mobilité de l'UE, font face à la problématisation des modes de vie non sédentaires et considèrent la mobilité comme une stratégie et une solution pour un processus ascendant de mondialisation et comme une partie intégrante des sociétés mobiles ouest-africaines ; qui existent à côté des modes africains de mobilisation devenus partie des régimes de mobilité européens. L'objectif de cette recherche est de promouvoir la recherche future en augmentant la

\footnotetext{
* Paper delivered at the '13th Summer School on Migrants, Human Rights and Democracy', held at Università di Palermo, on Jun. 10-14, 2019.

1 Masters in Arts candidate of the European Masters of Migration and Intercultural Relations (EMMIR) at the University of Oldenburg - Germany.
} 
visibilité et l'action politique des possibilités de transformation des modes de mobilisation africains.

Mots-Clés: Mobilisation, régimes de mobilité de l'UE, Afrique de l'Ouest.

\section{Introduction}

The current shared EU course on African migration is the result of a struggle throughout different eras of EU involvement in Africa: Colonisation, post-colonialism, development-cooperation and now securitisation (VENTURI, 2019); gradually focusing more on security and increasingly conceptualising migration as negative (SCHÖFBERGER, 2019). While most EU involvement in West-Africa is officially directed at improving governance, behind this is hidden an agenda of securitisation, more specifically the curbing of migration; thereby ignoring that most migrants move and remain within Western Africa (VENTURI, 2019).

The consequences of the restriction of intra-West-African movement that was common within the framework of ECOWAS (Economic Community of West African States) is that many migration processes and employment opportunities in trade and transport become illegalised and communities lose their livelihood (BRACHET, 2018). Overall, it seems as if good governance is merely a pretence to securitise Europe's external borders. Ironically, this securitisation generates the same migration and security problems, that the EU wants to inhibit, because former intra-regional migrants, traders and drivers might not find another resort than migrating to Europe or taking up weapons (BRACHET, 2018).

The externalisation of European borders has been in the focus of scholars for many years. However, there seems to be a lack of research on African modes of challenging these developments. Therefore, this paper focuses on West-African modes of mobilisations against the externalisation of European borders. West-Africa was chosen as 
the area of interest because European borders are increasingly manifested in the Sahel and beyond.

At the hands of a literature review, this paper examines recent publications in relation to this topic, guided by the following research question: How do West-African modes of mobilisations challenge EU mobility regimes? The following sub-questions complement the analysis: What are the processes in the externalization of European borders in WestAfrica? What are the consequences for West-African mobilities?

The analysis is guided by the concept of mobilisation. Rather than presenting results, the objective is to promote future research and to delve into the actors involved, their strategies and their demands to increase the visibility and political agency of the transformative possibilities of African modes of mobilisations.

\section{Conceptual framework}

Within this paper, the term "EU mobility regimes" (Schapendonk, 2017 ) is used rather than EU border regime to emphasise that the EU regime consists of multiple strategies restricting mobilities. Following the example of Landau (2019), I acknowledge that for the sake of analysis I use generalised conceptualisations of the European Union (EU) and Europe, and also (West-)Africa, that do not account for the complexities of these geographic and political bodies.

This paper examines mobilisations. 'To mobilise' means to "organize and encourage (a group of people) to take collective action in pursuit of a particular objective" and "bring (resources) into use for a particular purpose", but also "make (something) movable or capable of movement." (ENGLISH OXFORD LIVING DICTIONARIES, 2019). The use of the term 'mobilisations' allows an exploratory analysis and opens up space for various modes of private and public (non-) action (Ataç, Rygiel \& Stierl, 2016) as 
response to EU mobility regimes and at the same time entails a deeper meaning of challenging the restriction of mobility through movement.

\section{Methodology}

This research is an attempt to challenge dominant biases in African migration research and is oriented at a constructivist epistemology, the belief that "meanings are constructed, interpreted, and constantly reconstructed by people in their perceptions and social interactions" (CASTLES, 2012, p.19). This paper conceptualises migration as mobilities to confront the sedentary bias (URRY, 2007), to challenge universalised Western notions (MAVHUNGA, CUVELIER \& PYPE, 2016) and to emphasize the agency of migrants as actors of social transformation. The methods employed in this paper are oriented at a literature review. The main literature used is from the years 2016-2019, but in order to put the literature into context, also less recent literature is used. Some of the literature reflects the African context in general because only a limited amount of literature focuses explicitly on West-Africa.

In this paper, I engage in empirical generalisation to extrapolate general knowledge (LUND, 2014) from a limited array of literature. This generalisation is inevitable due to this paper being a small scope literature review. I would like the reader to keep in mind that the objective of this paper is not the generation of empirical results, instead, I aim to discover "connections and relations, not directly observable, by which we can understand and explain already known occurrences in a novel way" (DANERMARK et al. 2002, p.91 apud Lund, 2014).

\section{Strategies of Externalisation}


It is difficult to pinpoint the manifestations of European external borders because the EU is constantly engaging in new forms of border work (VAUGHAN-WILLIAMS, 2007). Next to the more known physical strategies of externalisation, such as providing surveillance and technical equipment, strengthening border controls and training border guards; there are other, mostly invisible strategies of externalisation that penetrate deeply into all spheres of African lives.

Landau (2019, p. 176) differentiates three main strategies: Counting and categorisation refer to the tracking of movements through surveillance systems and statistical collections; and the "sorting of "deserving" refugees and the highly skilled from ordinary, superfluous migrants". The sedentary subject and African space-time are created through awareness campaigns, stigmatisation and punishment of migrants, all aimed at fuelling feelings of patriotism and familial guilt, so that Africans contain themselves within their community, disconnected from global space-time (Landau, 2019, p. 178). This strategy of "containment development" aims at excluding Africans not only from European territory, "but from contemporary logics of mobility and global desire" (LANDAU, 2019, p.180).

EU migration policies are informed by narrative frames of a "migration-development-security nexus" (SCHÖFBERGER, 2019, p.7). However, Stern \& Öjendal (2010, p. 22) criticise the assumption that security and development are "known and knowable processes conditions or states of being that intersect". Instead, their research shows that the two terms embody various meanings and relationships and how they can be enacted in different discourses to justify policies.

\section{Mobilising against EU mobility regimes}

"Over the past decade, we have witnessed an upsurge of political mobilisation by refugees, irregularised migrants, and migrant solidarity 
activists in the countries of the European Union, at its external borders (...) and in other parts of the world (...)" (ATAÇ et al., 2016, p.527-528). The following part introduces African modes of mobilisations.

\subsection{West-African governments}

The EU's measures of curbing migration risk to affect local governance negatively and to inhibit local reforms and regional initiatives (VENTURI, 2019). The EU's “stick \& carrot approach" forces the implementation of EU migration policies in exchange for amongst others development aid; pushing their needs and interests in the background and restricting their national sovereignty and competences (Schöfberger, 2019, p.4).

Mobility restrictions cause discontent in the local populations. Therefore, Venturi (2019, p.17) emphasises the need for governments to include local communities and authorities, for example, traditional chiefs, and to develop alternative strategies that strengthen the "resilience capacities of local communities" instead of imposing external solutions; and to ensure that security controls do not inhibit the freedom of movement. Overall, Venturi's (2019) suggestions remain vague but provide a useful starting point, especially by pointing out that freedom of movement is crucial for the livelihood of the local population.

Venturi's (2019) analysis would be even more useful if the scholar would further elaborate on West-African governments' positions and already existing government initiatives and developments that challenge EU mobility regimes. An example of such mobilisation is the refusal of the Malian government to sign readmission agreements with the EU in 2009, after that the Malian Expelled Migrant Association called for the government to protect its nationals of expulsion (LECADET, 2017). 
Also, in 2018, many African governments spoke out against EU border policies such as the detention of migrants (SCHÖFBERGER, 2019). Following this example, West-African governments can challenge the EU's migration policies by arguing that they violate their sovereignty and their nationals' rights. However, it can be criticised that this mobilisation is still contained within a framework of bordered nations and might not ease mobilities of African migrants beyond national or continental borders.

\subsection{Local organisations}

A lot of research has been devoted to the EU's influence on African governments, but Exner and Hochleithner (2018) identified a research gap concerning local actors and institutions, a crucial part of West-African societies. Particularly independent grassroot movements are pushed into invisibility by NGOs and IGOs who are part of the EU's migration industry (TAZZIOLI \& WALTERS, 2019). Migration has become an ever-growing, commercialised business with an interest in keeping the industry alive (Smith \& Schapendonk, 2018).

In addition, the EU's security concerns seem to rule out other topics such as social and political activism and participation which is merely addressed in small-scale projects (VENTURI, 2019). Overall, the securitisation approach has increased inequalities and suppressed African actors with less political voice (SCHÖFBERGER, 2019).

For example, as a reaction to the EU's decentralisation strategy, traditional chiefs in the Sahel, unofficial representatives of their communities, try to maintain their power position through engaging in local politics. However, this "politicisation of chieftaincy" might weaken their legitimacy within the local population (VENTURI, 2019, p.13). This example shows the difficulty of challenging EU policies that are not well compatible with local contexts. 
Local initiatives can defend the African migrants' interests, but also engage in compliance with the EU and attempt to prevent migration for example through anti-migration campaigns (SMITH \& SCHAPENDONK, 2018). An example is the case of Senegalese mothers who protest against clandestine migration after having lost their family members (BOUILLY, 2016). Overall, local actors challenge EU mobility regimes with various strategies including mobilising against mobility.

\section{3 (Potential) Migrants}

Through the securitisation of EU mobility regimes, low skilled African migrants, asylum seekers and rural communities are confronted with solid borders (Schöfberger, 2019). Existing inequalities are augmented, because EU businesses, international organisation, and highly skilled migrants encounter liquid borders. Against that backdrop, Schöfberger (2019) points out the need for improving political representation at the (trans-) national level for the most disadvantaged groups. The scholar does not further elaborate on how this can be done but merely suggests it for future research.

Smith and Schapendonk (2018) believe that an intersectional approach is needed, that focuses on specific actors, in particular on migrants as trans-local, bottom-up actors for example through the means of remittances. The same approach is suggested by Exner \& Hochleithner (2018) who take the Senegalese Murid brotherhood youth organizations as an example of a trans-local and transnational actor who developed from facilitators of financial remittances to political non-state actors with the potential to push forward governance reforms.

An interesting example of would-be movers who developed bottom-up strategies to circumvent EU mobility regimes is introduced in Ceesay's (2016 apud SMITH \& SCHAPENDONK, 2018) research on 'beach boys' and 
'online hustlers' in the Gambia. Both groups try to establish (online) relationships with people from the Global North to obtain a positionality of global connectivity. Their broader aim is to end their often involuntarily immobility (Smith \& Schapendonk, 2018).

Another example of mobilisation is provided by Ndao (2012)'s research, who challenges the negative perceptions of child mobilities in West-Africa, that are often stigmatised as trafficking. Instead, according to Ndao (2012), children's (inter-)national mobility practices are part of the regions' history and are shaped by a thirst for knowledge, new perspectives, and the creation of new cultural models, thereby asserting themselves as modern, global actors.

These cases show that through the mere exercise of mobility, migrants can reshape their autonomy and agency and engage in "nomadic resistance" (LANDAU, 2019, p.182). Another example might be the diversification of African migration to North America, the Gulf and Asia, as a response to the immigration restriction imposed by the EU (Flahaux and De Haas, 2016). However, Landau (2019, p.182) also warns that resistance might trigger "greater forms of external and internal imperial interventions", thus, in the future, the Gulf and Asia might also attempt to solidify their borders for African migrants. This shows how African mobilisations bear the danger of causing more intrusive and pervasive controls imposed by the EU- and other political bodies.

\subsection{Expelled migrants}

Expelled migrants can become vocal public actors confronting expulsion policies from inside and beyond European borders through the support of expelled migrants associations. These associations transform the taboo and social marginalization associated with expulsion to a collective, political protest. On the forefront of this movement is the Malian Expelled 
Migrants Association (Association Malienne des Expulsés AME). These associations also exist in Mali, Togo, Cameroon and Senegal and they voice political demands not only to the EU but also to their own governments. Their tools for protests are media events, demonstrations, debates, participation in international immigration summits etc (LECADET, 2017). This form of mobilisation is not entirely new but expands the $19^{\text {th }}$-century workers' movements (LECADET, 2017).

These associations sometimes collaborate with left African parties, such as the African Independence Party which stands for "pan-African, working class, anti-colonialist and socialist" politics (LECADET, 2017, p. 152). Nevertheless, AME's strategy entailed the distancing from traditional politics, aiming at a more original representation of protests, with diverse forms of action, being aware of their vulnerability to political exploitation and hybridisation (Lecadet, 2017). For example, some associations orientate their demands at existing migration laws and work within the frameworks of governments, the International Organization for Migration (OIM) and the EU (LECADET, 2017).

In contrast, the AME refuses existing migration laws and demands for "freedom of movement, the sovereignty of the Malian state as an argument in favour of the non-subjugation of its policies to French migration policies, and the denunciation of the inhuman nature of expulsions", asking for a new policy reflecting migrants' perspectives (LECADET, 2017, p.159). The example of the AME shows how mobilisations can be built upon former movements and how tactics matter, because the migration industry will attempt to incorporate most mobilisations.

\subsection{Media, academia \& writers}

Exner and Hochleithner (2018) analysed international media narratives of West-African mobility. The most dominant narrative is "the 
wave of the destitute", thus victimising and securitising the migrant; and constructing the Sahel as a threatening space of crisis, extending to Europe (EXNER \& HOCHLEITHNER, 2018, p. 9). These authors (2018) conclude that media and policy narratives simplify the multi-causality of migration and ignore the perspective of West-African governments. Not only Western media narratives can strengthen European borders but also visual media strategies such as deportation movies screened in countries of origin (TYLER, 2018). Muppidi (2013, p.330) would probably define these strategies as part of the "economy of colonial truth".

Muppidi (2013) analyses within international relation studies, but I argue that the concept describes implicit strategies of EU mobility regimes. Muppidi (2013, p.307) criticises how the colonization of academia excludes other ways of learning and knowing. Berriane and Haas (2012) add that most research on African migration is funded and controlled by institutions of the Global North and consequently often reflects EU interests in security, for example by producing research on illegal migration and smuggling, thereby constructing migration as a problem. Landau (2019, p. 182) confirms this perspective by warning that "without a sound alternative base of knowledge and analysis, the European gaze will come to frame many Africans' self-understanding".

How can narrated borders be challenged? Muppidi (2013, p. 310) suggests that "if that 'object' of knowledge was something that we cared about and came to love, if it was presented not in its object-hood but in its intimate human relationship with us, then maybe a different orientation towards knowledge, responsibility, justice, and understanding might follow". However, this suggestion lacks concrete implementation proposals, the only concrete proposition so far is Muppidi 's (2013) recommendation of Chinua Achebe's 'Things Fall Apart' as an example of resistance through a narration of perspectives from the lower Niger. Laney et al. (2016) point out that migrants and other actors have been using social media to challenge 
dominant, negative media representations. Landau (2019, p. 182) also believes in counter-narratives, diasporic literature and politics that "reinscribe Africa into global circulations of ideas, people, and material".

\subsection{Transnational social movements}

Transnational social movements take shape in international migration forums and workshops organised by African or migrant networks, all striving towards challenging a global migration policy. These transnational social movements are positioned within a (post-)colonial framework, asking Europe to acknowledge its responsibility concerning poverty on the African continent and in repressing African migrants. These strategies are an example of how borders can be transformed to spaces of mobilisations, constantly (re-)inventing new forms of mobile and multi-sited protest and resistance against the restriction of the autonomy of migrants (LECADET, 2017) and especially African mobilities.

\section{Conclusion}

This paper looked at EU mobility regimes in West-Africa and at modes of mobilisations. I identified governments, local organisations, (potential) migrants, expelled migrants, media, academia and writers and transnational social movements as relevant actors with different modes of action.

The externalisation of European borders is manifested through physical and psychological strategies; border controls, tracking and surveillance and categorisation and stigmatisation of migrants. The African is conceptualised as a sedentary subject, disconnected from global spacetime. EU mobility regimes frame migration as a threat to be contained through securitisation and local development. 
The consequences for West- African actors are diverse. Governments are restricted in their national competences in exchange for positive incentives. Independent local organisations are pushed into invisibility, while the organisations that take part in the EU migration industry flourish. Especially low skilled African migrants, asylum seekers and rural communities are hindered in their mobilities, negatively affecting their livelihood. Expelled migrants are exposed to humiliation and social marginalisation. International media strengthens the EU's approach by victimizing and securitising the migrant and academia reflects the EU's interests in security.

Coming back to the research question 'How do West-African modes of mobilisations challenge EU mobility regimes?', there is no single answer, but this research presents a few cases to illustrate the diversity of African modes of mobilisations.

African governments refuse the implementation of EU migration policies based on their sovereignty and their nationals' right. Local organisations strengthen social and political activism, but they also mobilise against the mobilisations of some groups as shown by the Senegalese mothers campaigning against clandestine migration. Migrants geographically diversify their trajectories, they become trans-local and political actors such as the Senegalese Murid brotherhood youth organizations, would-be migrants challenge their unwanted immobility with creative strategies such as the hustlers in the Gambia and West-African children claim a place in the modern world through their mobility practices.

The Expelled Migrants Associations are an especially explicit example of mobilisations, through their non-traditional political protest. West- African authors challenge border narratives through their own narratives and social media opens more space for the voices of African migrants. Finally, the emergence of African transnational social movements challenges EU mobility regimes. 
To conclude, there are multiple African modes of mobilisations that challenge EU mobility regimes, confront the problematisation of nonsedentary lifestyles and see mobility as a strategy and a solution for a bottom-up process of globalisation and as an inherent part of West-African mobile societies; existing next to African modes of mobilisations that have become part of EU mobility regimes.

This research has certain limitations. First, the literature presented is mostly written by Western scholars. Second, the cases presented are reductionist and cannot account for the complexity of the topic, however, this research merely attempts to shed light at African modes of mobilisations. Due to the scope of the paper, different actors and strategies are presented shortly, thereby opening space for the readers' thoughts. Third, the writing is influenced by my own positionality, and by the frame of analysis established. Finally, this research is based on secondary data, in order to develop a greater understanding, a qualitative research approach is required that focuses on migrants' and relevant actors' agencies, capabilities and aspirations.

\section{References}

ATAÇ, I., RYGIEL, K., \& STIERL, M. Introduction: The Contentious Politics of Refugee and Migrant Protest and Solidarity Movements: Remaking Citizenship from the Margins. Citizenship Studies, v. 20, n. 5, pp. 527-544, 2016.

BERRIANE, M., \& DE HAAS, H. New Questions for Innovative Migration Research. In: BERRIANE, M. \& DE HAAS, H. (Eds.). African Migrations Research: Innovative Methods and Methodologies. Trenton: African World Press, 2012, pp. 1-14.

BOUILLY, E. Senegalese mothers 'fight clandestine migration': an intersectional perspective on activism and apathy among parents and spouses left behind. Review of African Political Economy, v. 43, n. 149, pp. 416-435, 2016.

BRACHET, J. Manufacturing Smugglers: From Irregular to Clandestine Mobility in the Sahara. The Annals of the American Academy of Political and Social Science, v. 676 , n. 1, pp. 16-35, 2018.

CASTLES, S. Methodology and Methods: Conceptual Issues. In: BERRIANE, M. \& DE HAAS, H. (Eds.). African Migrations Research: Innovative Methods and Methodologies. Trenton: African World Press, 2012, pp. 15-36. 
EXNER, A. \& HOCHLEITHNER, S. A Review of Literature and Media Narratives with focus on West African Sahel. (Swedish International Centre for Local Democracy No.13). Visby: ICLD, 2018.

FLAHAUX, M.-L., \& DE HAAS, H. African Migration: Trends, Patterns, Drivers. Comparative Migration Studies, v. 4, n. 1, 2016.

HARNEY, N. The Ritualisation of Hospitality: Comparative Notes at the Frontiers of Migration. In: NUCIFORA, M. \& MILITELO, P. (Eds.). Frontiers, Migrations, Anchorings / Frontières, migrations, ancrages / Frontiere, migrazioni, ancoraggi. Palermo: New Digital Frontiers, 2017, pp. 235-239

LANDAU, L. B. A Chronotope of Containment Development: Europe's Migrant Crisis and Africa's Reterritorialisation. Antipode, v. 51, n. 1, pp. 169-186, 2019.

LANEY, H. M., LENETTE, C., KELlETT, A. M., SMEDLEY, C., \& KARAAN, P. "The most brutal immigration regime in the developed world": International Media Responses to Australia's Asylum-Seeker Policy. Refuge: Canada's Journal on Refugees, v. 32, n. 3, pp. 135-149, 2016.

LECADET, C. Europe Confronted by Its Expelled Migrants: The Politics of Expelled Migrants' Associations in Africa. In: GENOVA, N. (Ed.). The Borders of Europe: Autonomy of Migration, Tactics of Bordering. London: Duke University Press, 2017, pp. 141-164.

LUND, C. Of What is This a Case?: Analytical Movements in Qualitative Social Science Research. Human Organization, v. 73, n. 3, pp. 224-234, 2014.

MAVHUNGA, C. C., CUVELIER, J., \& PYPE, K. "Containers, Carriers, Vehicles": Three Views of Mobility from Africa. Transfers, v. 6, n. 2, 2016.

MUPPIDI, H. On The Politics of Exile. Security Dialogue, v. 44, n. 4, pp. 299-313, 2013.

NDAO, A. Anthropological Approaches to Studying the Mobility of Children in West Africa. In: BERRIANE, M. \& DE HAAS, H. (Eds.). African Migrations Research: Innovative Methods and Methodologies. Trenton: African World Press, 2012, pp. 235-254.

ENGLISH OXFORD LIVING DICTIONARIES, 2019. Accessed on: $<$ https://en.oxforddictionaries.com/definition/mobilize>. Last visited on sept. 2019.

SCHAPENDONK, J. The multiplicity of transit: the waiting and onward mobility of African migrants in the European Union. Int. J. Migration and Border Studies, v. 3, n. 2/3, pp. 208-227, 2017.

SCHÖFBERGER, I. Migration: solid nations and liquid transnationalism? The EU's struggle to find a shared course on African migration 1999-2019. (Discussion Paper 1/2019). Bonn: German Development Institute, 2019.

SMITH, L., \& SCHAPENDONK, J. Whose Agenda? Bottom up Positionalities of West African Migrants in the Framework of European Union Migration Management. African Human Mobility Review, v. 4, pp. 1175-1204, 2018.

STERN, M., \& ÖJENDAL, J. Mapping the Security: Development Nexus: Conflict, Complexity, Cacophony, Convergence? Security Dialogue, v. 41, n. 1, pp. 5-29, 2010.

TAZZIOLI, M., \& WALTERS, W. Migration, solidarity and the limits of Europe. Global Discouse, v. 9, n. 1, pp. 175-190, 2019.

TYLER, I. Deportation Nation. Journal for the Study of British Cultures, v. 25, n. 1, 2018.

URRY, J. Mobilities. Cambridge: Polity, 2007. 
VAUGHAN-WILLIAMS, N. Borderwork beyond Inside/Outside? Frontex, the CitizenDetective and the War on Terror. Space and Polity, v. 12, n. 1, pp. 63-79, 2008.

VENTURI, B. An EU Integrated Approach in the Sahel: The Role for Governance. IAI, v. 19, 2019.

Artigo recebido em: 17/09/2019.

Aceito para publicação em: 27/09/2019. 